\title{
Multiple pharmacological interventions targeting cardiovascular disease risk factors in individuals with type 2 diabetes-systematic review
}

\author{
Hanan Khalil ${ }^{1 *}$, Mc Namara K ${ }^{2,3}$ and Pan $\mathrm{Y}^{2}$ \\ *Correspondence: hanan.khalil@monash.edu \\ ${ }^{1}$ Monash University, Faculty of Medicine, Nursing and Health Sciences, School of Rural Health, PO Box 973, Moe, Vic 3825, \\ Australia. \\ ${ }^{2}$ Monash University, Faculty of Pharmacy and Pharmaceutical Sciences, School of Rural Health 381 Royal Parade Parkville, \\ Vic 3052, Australia. \\ ${ }^{3}$ Deakin University and Flinders University, Greater Green Triangle University Department of Rural Health, Warrnambool, \\ Vic 3280, Australia.
}

\begin{abstract}
Background: The use of pharmacological agents has been shown to slow down the progression of microvascular and macrovascular complications. Most clinical trials address one pharmacological intervention at a time. To date, only a few studies explored multi-factorial pharmacological interventions in T2DM individuals for preventing CVD related complications. Given the current therapeutic inertia in pharmacological management of CVD risk factors, it is important to establish the benefits of a more holistic approach. Therefore, the aim of this review is to assess the efficacy of multiple pharmacological interventions for cardiovascular diseases (CVD) risk factors with or without conventional care in reducing all cause mortality, CVD mortality, stroke and cardiovascular events among adults with type 2 diabetes. Current evidence fails to support the benefit of multiple pharmacological interventions on all cause mortality and death from cardiovascular causes. However, beneficial effects were seen on the reduction of the overall number of cardiovascular events and there were promising trends for secondary outcomes such as stroke, myocardial infarction, revascularisation and amputation.
\end{abstract}

Keywords: Cardiovascular risk factors, diabetes, mortality, pharmacological interventions, systematic review

\section{Introduction}

Around 300 million people worldwide have diabetes [1]. Moreover diabetes related deaths are projected to double between 2005 and 2030 [1,2]. Patients with type 2 diabetes mellitus (T2DM) are at risk of developing cardiovascular diseases (CVD) and other complications such as blindness, end stage renal impairment and lower limb amputations in some circumstances $[3,4,5]$. CVD is responsible for about $80 \%$ of the total mortality in individuals with T2DM, contributing substantially to direct health care costs and decreased quality of life $[6,7,8]$.

Interventions targeted at preventing CVD onset for high risk individuals with T2DM can delay or reduce the progression of complications related with diabetes $[9,10,11]$. In addition, CVD prevention programs used in several countries have led to reduction in diabetes-related complications $[10,11,12]$. These programs were aimed at diet modification, promotion of physical activity, weight loss, smoking cessation, educational counselling and/ or pharmacological interventions. Moreover, several studies have addressed several combinations of the above mentioned interventions $[12,13,14]$.

The United Kingdom Prospective Diabetes Study (UKPDS) identified several important CVD risk factors in individuals with T2DM including hyperglycaemia, hypertension and dyslipidaemia $[15,16,17]$. Comprehensive management of glucose, blood pressure and lipid levels is essential to the provision of best care to individuals with T2DM $[16,17,18]$.

The use of pharmacological agents in addition to lifestyle modification has been shown to slow down the progression of microvascular and macrovascular complications $[19,20,21,22]$. Most clinical trials address one pharmacological intervention at a time in addition to lifestyle modifications [23-30]. To date, only a few studies explored multi-factorial pharmacological interventions in T2DM individuals for preventing CVD related complications. Most of these studies were a cohort design, and more accurately evaluated the efficacy or effectiveness of CVD risk management programs incorporating single pharmacological strategies [31,34]. Given the current therapeutic inertia in pharmacological management of CVD risk factors, it is important to establish the benefits of a more holistic approach. The current proposed systematic review will only focus on RCTs designed to evaluate the specific effect of multiple pharmacological interventions (with or without lifestyle modifications) to optimise management of CVD risk factors on cardiovascular outcomes and mortality in patients with type 2 diabetes.

\section{Objectives}

To assess the efficacy of multiple pharmacological interventions (with or without lifestyle modifications)

C 2013 Khalil et al; licensee Herbert Publications Ltd. This is an Open Access article distributed under the terms of Creative Commons Attribution License (http://creativecommons.org/licenses/by/3.0). This permits unrestricted use, distribution, and reproduction in any medium, provided the original work is properly cited. 
to optimise management of multiple CVD risk factors on cardiovascular outcomes and mortality in patients with type 2 diabetes.

\section{Search and study selection}

Ovid MEDLINE ${ }^{\circledR}$ (1948 to present with daily update), Cochrane Central Register of Controlled Trials (4th Quarter 2010) and Embase were searched for papers dating from 1995 to February 2012: this timeframe was chosen because the landmark publications for clinical trials demonstrating cardiovascular benefits of statins began being published from 1994 [35,36]. Clinical trials for key weight loss therapies such as orlistat and sibutramine also emerged after this period. We used the relevant diagnostic terms (e.g. cardiovascular disease, stroke, coronary disease, mortality, and diabetes mellitus type II), together with text word searches for specific interventions (e.g. antihypertensives, blood pressure control, hypolipidemic agents, lipid-lowering therapy, weight management, smoking cessation, aspirin, anticoagulants). Text word searches using the terms "multiple", "multifaceted" and "multifactorial" were applied. Specific interventions of interest were searched including antihypertensive management, smoking cessation, lipid lowering drugs management, aspirin, antiplatelet, anticlotting factors and obesity drugs. Disease terms such as diabetes, type 2 diabetes and diabetes mellitus were also used as shown in Appendix 1. This was supplemented by examining the reference lists of each Randomised Controlled Trial (RCT) study identified. We limited the review to English language articles. Authors were also contacted for the raw data if it was not stated in the paper.

The original search titles and abstracts obtained through searches were checked independently by two reviewers (HK and YP). Each paper thought to be of possible relevance was obtained and read by all three reviewers (HK, KM and YP) independently to determine whether it fitted specified inclusion criteria. Disagreements were discussed and resolved between the three reviewers.

\section{Inclusion and exclusion criteria}

RCTs identified for the primary or secondary prevention of CVD in patients with type 2 diabetes by means of multiple risk factor pharmacological interventions were included in the review (i.e. separate pharmacological intervention strategies for two or more CVD risk factors such as blood pressure reduction, lipid management, antiplatelet therapy, smoking cessation and weight reduction, excluding glycaemic control). Comparators are defined as conventional care. They could be with or without non-pharmacological treatments (such as counselling or education, behavioural interventions). Trials aimed at patients with any stage of their diabetes and located in middle- to high-income countries were included. Children under 18 and of duration less than six months were excluded.

\section{Outcomes of interest}

The primary outcome of interest was reduction in mortality in a head to head comparison. The secondary outcome of interest was a reduction in the total number of cardiovascular events. Other outcomes such as stroke, myocardial infarction, revascularisation, amputation or other cardiovascular related events reported as a first cardiovascular event were also included.

\section{Quality control}

Relevant data were extracted from each study as shown in Table 1. Information such as author, publication year, trial duration, number of patients in the study, patients' age, description of the intervention, findings and authors' conclusion were collected. Full paper assessments for quality were completed independently by two reviewers (HK and KM). Data extraction was undertaken by HK and reviewed by the other researchers $[38,39]$.

The methodological quality of the studies that met the inclusion criteria was assessed using the components of the study design most closely aligned to internal validity as suggested by the Cochrane Collaboration [38]. These components include: adequate description of randomisation, blinding of patients and outcome assessors and adequate description of follow up and withdrawals.

\section{Statistical analysis}

A meta-analysis was performed only on the results extracted from three studies. We analysed the data using the standardised data extraction tool from the Revman v.5 package and all results were presented with a $95 \%$ confidence Interval $(\mathrm{Cl})[38,39]$. We compared dichotomous data using Risk Ratio (RR). Heterogeneity, (I2) which describes the proportion of total variation in study estimates that is due to variability, was assessed using the standard chisquared. Study data was considered heterogeneous if 12 statistic was $>50 \%$. For the forest plot, we used the random effect method due to the variability of the participants (newly diagnosed versus patients with past diagnosed diabetes) in all three studies [38].

\section{Results}

We found a total of 64 potentially relevant citations from Medline, Embase, Cochrane trials register and hand searches. After removal of all duplicates, 48 reporting clinical data were retained. Only ten addressed the impact of multiple pharmacological interventions on CVD risk factors in type 2 diabetes (Figure 1) [41-50].

Seven of these ten trials were excluded because they did not address the outcomes of interest. Details of the remaining three studies are summarized in Table 1. In general, all studies compared an intervention group allocated to multi-drug therapy such as anti-hypertensive and hypolipidaemic therapy commonly, and occasionally aspirin in addition to the other two treatments-versus a 
Khalil et al. Journal of Diabetes Research \& Clinical Metabolism 2013,

http://www.hoajonline.com/journals/pdf/2050-0866-2-9.pdf

Table 1. Multiple risk factor intervention trials.

\begin{tabular}{|c|c|c|c|c|c|c|}
\hline Study & Sample & $\begin{array}{l}\text { Sample size, mean } \\
\text { age at baseline }\end{array}$ & Intervention & Outcomes measured & $\begin{array}{l}\text { Duration of follow } \\
\text { up }\end{array}$ & Finding \\
\hline $\begin{array}{l}\text { Gaede et al., } 2008 \\
\text { (Steno-2 study) }^{47}\end{array}$ & $\begin{array}{l}\text { Patients with type } \\
2 \text { diabetes and } \\
\text { persistent } \\
\text { microalbuminuria }\end{array}$ & $\begin{array}{l}160 \text { patients, } \\
(55.1 \pm 7.2)\end{array}$ & $\begin{array}{l}\text { All patients in the intensive } \\
\text { treatment group were } \\
\text { prescribed blockers of } \\
\text { the renin angiotension } \\
\text { system regardless of blood } \\
\text { pressure and received low } \\
\text { dose aspirin as primary } \\
\text { prevention. Behaviour } \\
\text { modification and a } \\
\text { stepwise pharmacological } \\
\text { therapy for blood } \\
\text { pressure, dyslipidaemia } \\
\text { and hyperglycaemia } \\
\text { were also overseen by } \\
\text { a project team (doctor, } \\
\text { nurse and dietitian). } \\
\text { The intensive therapy } \\
\text { group were treated at a } \\
\text { specialist diabetes centre } \\
\text { and had defined targets } \\
\text { consistent with the latest } \\
\text { guidelines of the American } \\
\text { Diabetes Association. The } \\
\text { control group received } \\
\text { conventional treatment for } \\
\text { multiple risk factors from } \\
\text { their general practitioner, } \\
\text { according to the } 1988 \\
\text { recommendations of the } \\
\text { Danish Medical Association } \\
\text { (which did not include } \\
\text { intensive pharmacological } \\
\text { therapy) }\end{array}$ & $\begin{array}{l}\text { Cardiovascular events, } \\
\text { including death from } \\
\text { cardiovascular causes, } \\
\text { non fatal stroke, non fatal } \\
\text { myocardial infarction, } \\
\text { coronary artery bypass } \\
\text { grafting (CABG), } \\
\text { percutaneous coronary } \\
\text { intervention (PCI), } \\
\text { revascularization for } \\
\text { peripheral atherosclerotic } \\
\text { disease and amputation. }\end{array}$ & $\begin{array}{l}\text { The mean treatment } \\
\text { period was } 7.8 \\
\text { years. Patients } \\
\text { were subsequently } \\
\text { followed } \\
\text { observationally for } \\
\text { a mean of } 5.5 \text { years. } \\
\text { The primary end } \\
\text { point at } 13.3 \text { years } \\
\text { of follow up was the } \\
\text { time to death from } \\
\text { any cause. }\end{array}$ & $\begin{array}{l}\text { Intensive intervention } \\
\text { with multiple drug } \\
\text { combinations and } \\
\text { behaviour modification } \\
\text { had beneficial effects } \\
\text { on cardiovascular } \\
\text { complications and } \\
\text { rates of death from any } \\
\text { cause. The rate of death } \\
\text { among patients in the } \\
\text { conventional group was } \\
50 \% \text { compared with } \\
30 \% \text { in the intensive } \\
\text { treatment group } \\
\text { which indicates poor } \\
\text { prognosis for patients } \\
\text { in the absence of } \\
\text { intensive treatment. }\end{array}$ \\
\hline Joss et al., $2004^{50}$ & $\begin{array}{l}\text { Patients with type } \\
2 \text { diabetes and } \\
\text { nephropathy }\end{array}$ & $\begin{array}{l}90 \text { patients } \\
(63 \pm 7)\end{array}$ & $\begin{array}{l}\text { The intensive treatment } \\
\text { group was introduced in } \\
\text { steps starting with blood } \\
\text { pressure and cholesterol } \\
\text { management followed } \\
\text { by dietary intervention. } \\
\text { The control group had } \\
\text { conventional management. }\end{array}$ & $\begin{array}{l}\text { Clinical/Biochemical } \\
\text { factors such as BP, HbAlc, } \\
\text { lipids and BMI were } \\
\text { measured. Cardiovascular } \\
\text { events such as death, } \\
\text { amputation or heart } \\
\text { failure were reported. } \\
\text { The rate of progression } \\
\text { of renal disease in the } \\
\text { second year of follow up } \\
\text { was also measured. }\end{array}$ & 2 years & $\begin{array}{l}\text { Significant } \\
\text { improvement in BP, } \\
\text { lipids and creatinine } \\
\text { clearances were seen in } \\
\text { the intensive treatment. } \\
\text { The number of } \\
\text { cardiovascular events in } \\
\text { the intensive treatment } \\
\text { was significantly lower } \\
\text { than the control group. }\end{array}$ \\
\hline $\begin{array}{l}\text { Griffen et al., } 2011 \\
\text { (A D D I T I O N - } \\
\text { Europe) study }{ }^{37}\end{array}$ & $\begin{array}{l}\text { Screen-detected } \\
\text { patients with type } \\
2 \text { diabetes }\end{array}$ & $\begin{array}{l}3055 \text { patients } \\
(60.3 \pm 6.9)\end{array}$ & $\begin{array}{l}\text { The protocol is } \\
\text { characterised by intensive } \\
\text { treatment of glucose, } \\
\text { blood pressure and lipids } \\
\text { and structured lifestyle } \\
\text { education (dietary } \\
\text { modification, weight loss, } \\
\text { increased physical activity, } \\
\text { smoking cessation and } \\
\text { improving adherence to } \\
\text { medication). The intensive } \\
\text { therapy group had defined } \\
\text { targets for each treatment } \\
\text { unlike the control group } \\
\text { patients who received usual } \\
\text { care. }\end{array}$ & $\begin{array}{l}\text { Clinical/Biochemical } \\
\text { parameters were collected } \\
\text { such as BP, HbAlc and } \\
\text { lipids. The primary } \\
\text { endpoint was a composite } \\
\text { of first cardiovascular } \\
\text { event, including } \\
\text { mortality, morbidity, } \\
\text { revascularisation } \\
\text { and amputation. The } \\
\text { secondary endpoints } \\
\text { were the individual } \\
\text { components of the } \\
\text { primary endpoint and } \\
\text { all-cause mortality. }\end{array}$ & 5.3 years & $\begin{array}{l}\text { Improvements in } \\
\text { cardiovascular risk } \\
\text { factors were slightly } \\
\text { but significantly } \\
\text { better in the intensive } \\
\text { group. The incidence } \\
\text { of first cardiovascular } \\
\text { event was } 7.2 \% \text { in the } \\
\text { intensive group and } \\
8.5 \% \text { in the routine care } \\
\text { group and of all cause } \\
\text { mortality } 6.2 \% \text { and } \\
6.7 \% \text { respectively. }\end{array}$ \\
\hline
\end{tabular}

control group. Counselling and/or behavioural intervention were also provided described in both groups of the studies included in the review as shown in Appendix 2. The three trials had 3305 patients in total with type 2 diabetes. Patients' ages ranged from 7-70 years. Duration of follow up ranged from 2 to 13.3 years.

\section{Primary outcomes: mortality and morbidity}

All three trials reported positive changes in clinical parameters as well as biochemical variables in favour of the intervention group. However not all trials described details of mortality rates (Figure 2, Appendix 3).

\section{All cause mortality}

A lack of evidence exists to support a reduction of death from any cause was observed in favour of the intervention group with a RR of 0.77 [95\% Cl, $0.50-1.18]$.

\section{Death from cardiovascular cause}

There is a lack of evidence to suggest a significant risk reduction of death from CVD which favoured the multifactorial pharmacological intervention; $\mathrm{RR}=0.71$ [95\% Cl, $0.40-1.26]$. 


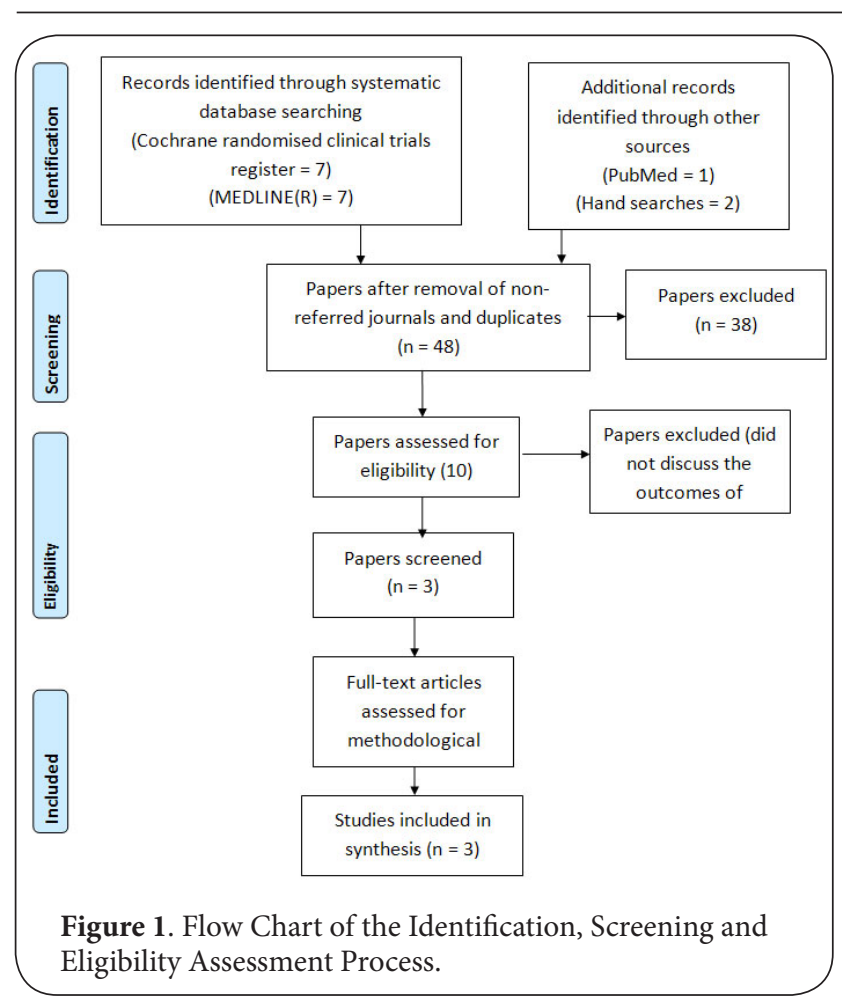

Figure 2. All measured outcomes.

\begin{tabular}{|c|c|c|c|c|}
\hline Outcome & Studies & Participants & Statistical method & $\begin{array}{l}\text { Effect } \\
\text { Estimate }\end{array}$ \\
\hline $\begin{array}{l}\text { All cause } \\
\text { mortality }\end{array}$ & 3 & 3260 & $\begin{array}{l}\text { Risk Ratio } \\
\text { (M-H, Random, 95\%CI) }\end{array}$ & $\begin{array}{l}0.77 \\
{[0.50,1.18]}\end{array}$ \\
\hline $\begin{array}{l}\text { Death from } \\
\text { cardiovascular } \\
\text { causes }\end{array}$ & 3 & 3260 & $\begin{array}{l}\text { Risk Ratio } \\
\text { (M-H, Random, 95\%CI) }\end{array}$ & $\begin{array}{l}0.71 \\
{[0.40,1.26]}\end{array}$ \\
\hline $\begin{array}{l}\text { Non-fatal } \\
\text { Myocardial } \\
\text { Infarction }\end{array}$ & 3 & 3260 & $\begin{array}{l}\text { Risk Ratio } \\
\text { (M-H, Random, 95\%CI) }\end{array}$ & $\begin{array}{l}0.68 \\
{[0.45,1.05]}\end{array}$ \\
\hline Non-fatal stroke & 3 & 3260 & $\begin{array}{l}\text { Risk Ratio } \\
\text { (M-H, Random, 95\%CI) }\end{array}$ & $\begin{array}{l}0.58 \\
{[0.24,1.38]}\end{array}$ \\
\hline $\begin{array}{l}\text { Amputation/ } \\
\text { Revascularisation }\end{array}$ & 3 & 3260 & $\begin{array}{l}\text { Risk Ratio } \\
\text { (M-H, Random, 95\%CI) }\end{array}$ & $\begin{array}{l}0.76 \\
{[0.52,1.09]}\end{array}$ \\
\hline $\begin{array}{l}\text { Total } \\
\text { cardiovascular } \\
\text { events }\end{array}$ & 3 & 3260 & $\begin{array}{l}\text { Risk Ratio } \\
\text { (M-H, Random, 95\%CI) }\end{array}$ & $\begin{array}{l}0.63 \\
{[0.43,0.94]}\end{array}$ \\
\hline
\end{tabular}

\section{Secondary outcomes}

Number of total cardiovascular events

All three trials reported on the total number of individuals experiencing events during follow up. They demonstrated a significant reduction in the total number of events in favour of the intervention group; $\mathrm{RR}=0.63[95 \% \mathrm{Cl}, 0.43-0.94]$.

\section{Myocardial infarction (MI)}

The combined trial results indicate a non-significant reduction of $\mathrm{MI}$ risk in favour of the intervention group with a RR of $0.68[95 \% \mathrm{Cl}, 0.45-1.05]$.

\section{Revascularisation and amputation}

The included studies reported on revascularisation/amputation as a combined outcome, and the reduction in the combined risk of amputation or/ revascularisation observed in favour of the intervention group was not significant, with a RR of $0.76[95 \% \mathrm{Cl}, 0.52-1.09]$.

\section{Stroke}

A lack of evidence exists in favour of the intervention group with a RR of 0.58 [95\% Cl, $0.24-1.38]$ to support a reduction of stroke.

\section{Publication bias}

We explored publication bias for all outcomes using a funnel plot. Visual inspection suggested symmetry for the primary and secondary outcomes, indicating no publication bias.

\section{Methodological quality of included trials}

We collected data for four methodological features of the identified studies and they were:

1. Allocation concealment

2. Randomisation

3. Double blinding

4. Outcome assessment

Allocation concealment means that the participant and others directly involved in treatment do not know to which treatment group the participant had been allocated. Randomisation ensured an equal chance of receiving the possible treatment. Double-blinding means that neither the participant nor the outcome assessor was aware of the identity of the treatment.

All three studies had a low risk of bias based on the above methodological features. In all included studies, Allocation to treatment groups was concealed and randomisation was done by an independent person such as a statistician or a computer. Double blinding was not employed in all three studies due to the nature of the interventions.

\section{Discussion}

Multi-factorial intervention of the cardiovascular risk factors is widely recognised as effective in the successful management of patients with type 2 diabetes.

This meta-analysis of three randomised controlled trials employing intensive pharmacological intervention for CVD risk factors demonstrated a non-significant reduction in the likelihood of death from any cause and risk of cardiovascular events such as myocardial infarction, stroke, amputation and revascularisation. There was, however, a significant reduction in the total number of cardiovascular events in favour of the intensive pharmacological CVD intervention group. These results could be attributed to either the additional behavioural interventions described in the included studies or the actual intensive pharmacological treatment given to the participants. Behavioural interventions are known to influence adherence to medications $[13,14,51]$. This 
Khalil et al. Journal of Diabetes Research \& Clinical Metabolism 2013,

study also confirms the relative absence of trials examining endpoints for this important topic. We believe this to be the first comprehensive meta-analysis of this topic and hence will serve as a valuable overview of current evidence for clinicians and researchers.

Only three studies fulfilled our inclusion criteria of the review as shown in. All three studies reported on improvement in clinical and biochemical parameters in favour of the intervention groups. Differences in the risk ratio for all components of the primary and secondary outcomes favoured the intensive intervention groups. Differences in risk reduction were greatest for the total cardiovascular events and smallest for all cause mortality.

The large confidence intervals obtained for the primary outcome suggests that there is lack of evidence to suggest improvements in these outcomes. As for the secondary outcomes, significant risk reduction was only observed in the total number of cardiovascular events, in favour of the intervention group.

The lack of significance benefit observed in our study could be also attributed to several reasons such as; health professional adherence to treatments algorithms, medication/ lifestyle adherence by patients, the timing and nature of drugs prescribed, and the use of specific drug combinations. Another important factor to consider is the method of randomisation described in the studies was vastly different; cluster randomisation of the general practices rather than the individuals was used in the Addition-Europe study to achieve high participants' retention.

The diversity of study designs and populations, the complex nature of the intervention itself and the lack of studies addressing our aims such as a reduction in mortality and morbidity precluded a significant number of studies to be included in our current review. The patients with diabetes involved in the three studies were a combination of newly diagnosed as well as patients with existing diabetes and with either microalbuminurea or nephropathy. The types of interventions also varied between the studies. The results of this review also highlight the lack of studies addressing the various populations and the multiple treatment algorithms. Newly diagnosed diabetes may differ in their response to CVD multifactorial pharmacological interventions from those who have been diagnosed for several years.

It is worth pointing out that it is not common practice but it is acceptable to combine results from cluster RCTs to non-cluster RCTs in the same analysis depending on the clinical/practical reasons. Given the large number of participants included in the cluster RCT by Griffen et al., 2011 and the use of raw numbers of participants in our analysis, it was deemed appropriate to combine the studies in our meta-analysis.

Statistical and clinical heterogeneity in our analysis presented some difficulties, particularly for multifactorial interventions due to the variation in population sampled and to the nature and context of the interventions. The potential effect of setting should also be considered as a possible explanation for heterogeneous results. Delivery of the ADDITION intervention was in primary care and largely by doctors and nurses; conversely, the other two trials involved multidisciplinary teams in specialist centres. As the number of studies addressing the efficacy of such interventions increase, a better picture will emerge on the overall efficacy of these interventions in the various populations.

It is possible that benefits cannot be detected in the early stages but emerge over time. This was clearly a potential factor preventing demonstration of significant benefit in the ADDITION-Europe primary endpoints. Lower than expected CVD incidence rates might well have contributed to the observation of non-significant differences to CVD endpoints, albeit in favour of the intensive intervention group [35]. Survival curves suggest benefits were only emerging at four years overall, although significant benefits from intensive treatment were demonstrated for the older (higher risk) subgroup. In addition, small but significant improvements to CVD risk factors had been demonstrated to suggest potential longer-term benefits. Longer follow up of patients involved will test whether intensive multifactorial treatment reduced cardiovascular risk in the long term as seen in the UKPDS. The current emphasis on early diagnosis, diabetes education and the availability of a wide range of therapeutic regimens with safer side effect profile make it easier to achieve good glycaemic control and control of CVD risk factors in patients with type 2 diabetes using intensified multifactorial regimes. However, therapeutic inertia and poor control of key CVD risk factors for patients with diabetes remain across most settings internationally. Our findings are important as a means of highlighting to health professionals the potential long-term benefits of early and holistic approaches to disease state management in diabetes. Considering the differences in outcomes between different interventions however, this benefit may be greater for patients with complications from diabetes, and when the intervention is delivered in well-resourced settings. Factors that need to be considered include the cost of treatment as these patients are taking multiple medications for their CVD risk factors, the effect of more complex medication regimens on patient adherence, and the availability of resources such as regular medical care and updated clinical practice guidelines to implement multifactorial pharmacological intervention for CVD risk factors in patient with type 2 diabetes. If approved for use, the much-anticipated 'polypill', combining aspirin with antihypertensive and lipid-modifying agents into a single pill, may assist with cost and lipid lowering drugs issues associated with more complex medication regimes.

The limitations of our results lie in the small number of studies included in this review. The three trials also have slightly different patient groups and interventions. Programs involving multiple CVD risk factor pharmacological 
management is likely to be effective but there are a number of possible treatment algorithms not tested, the detail around counselling is poorly defined and therefore difficult to reliably replicate in practice and we cannot differentiate the drug vs. counselling benefit very well. Furthermore, our search strategy focussed on identifying trials with a clear pharmacological focus. It did not include trials where the intervention was primarily concerned with health professional behaviour change.

\section{Implications for research}

The current systematic review highlights the shortcomings in the published trials of multi-factorial pharmacological intervention in patients with type 2 diabetes. There is a lack of such studies across different populations and settings with a large number of participants that are powered enough to detect a change on mortality. There is also a need for long-term follow up of trials addressing mortality and morbidity among patients with newly diagnosed diabetes, to confirm the benefits of early intensive treatment. Most of the trials report on biochemical and clinical parameters. More research is needed to address this very gap in the literature.

Research on the effects and costs of health protection and CVD risk prevention would be of direct policy relevance. Furthermore, qualitative studies examining how participants perceive and respond to the advice and treatment given in these randomised controlled trials could be very helpful in shaping future interventions and clinical guidelines.

\section{Additional files}

Appendix 1
Appendix 2
Appendix 3

Competing interests

The authors declare that they have no competing interests.

Publication history

Received: 09-Nov-2012 Revised: 29-Jan-2013

Accepted: 04-Feb-2013 Published: 21-Feb-2013

\section{References}

1. Shaw JE, Sicree RA, Zimmet PZ: Global estimates of the prevalence of diabetes for 2010 and 2030. Diabetes Res Clin Pract 2010, 87:4-14. | Article I PubMed

2. Wild S, Roglic G, Green A, Sicree R, King H: Global prevalence of diabetes: estimates for the year 2000 and projections for 2030. Diabetes Care 2004, 27:1047-1053. | Article | PubMed

3. Saydah SH, Eberhardt MS, Loria CM, Brancati FL: Age and the burden of death attributable to diabetes in the United States. Am J Epidemiol 2002, 156:714-719. | Article | PubMed

4. Yamagishi S: Cardiovascular disease in recent onset diabetes mellitus. J Cardiol 2011, 57:257-262. | Article | PubMed

5. Betteridge DJ: Lipid control in patients with diabetes mellitus. Nat Rev Cardiol 2011, 8:278-290. | Article | PubMed

6. Parati G, Bilo G, Ochoa JE: Benefits of tight blood pressure control in diabetic patients with hypertension: importance of early and sustained implementation of effective treatment strategies.
Diabetes Care 2011, 34 Suppl 2:S297-303. | Article I PubMed

7. Haffner SM, Lehto S, Ronnemaa T, Pyorala K, Laakso M: Mortality from coronary heart disease in subjects with type 2 diabetes and in nondiabetic subjects with and without prior myocardial infarction. $N$ Engl J Med 1998, 339:229-234. | Article I PubMed

8. Wild SH, Dunn CJ, McKeigue PM, Comte S: Glycemic control and cardiovascular disease in type 2 diabetes: a review. Diabetes Metab Res Rev 1999, 15:197-204. | Article | PubMed

9. Buse JB, Ginsberg HN, Bakris GL, Clark NG, Costa F, Eckel R, Fonseca V, Gerstein HC, Grundy S, Nesto RW, Pignone MP, Plutzky J, Porte D, Redberg R, Stitzel KF, Stone NJ: Primary prevention of cardiovascular diseases in people with diabetes mellitus: a scientific statement from the American Heart Association and the American Diabetes Association. Circulation 2007, 115:114-126. | Article | PubMed

10. Brown A, Reynolds LR and Bruemmer D: Intensive glycemic control and cardiovascular disease: an update. Nat Rev Cardiol 2010, 7:36975. | Article | PubMed

11. Narayan KM and Williamson DF: Prevention of type 2 diabetes: risk status, clinic, and community. J Gen Intern Med 2010, 25:154-7. Article | PubMed Abstract | PubMed Full Text

12. Brand-Miller J, Hayne S, Petocz P and Colagiuri S: Low-glycemic index diets in the management of diabetes: a meta-analysis of randomized controlled trials. Diabetes Care 2003, 26:2261-7. | Article I PubMed

13. Sixt S, Beer S, Bluher M, Korff N, Peschel T, Sonnabend M, Teupser D, Thiery J, Adams V, Schuler $G$ and Niebauer J: Long- but not shortterm multifactorial intervention with focus on exercise training improves coronary endothelial dysfunction in diabetes mellitus type 2 and coronary artery disease. Eur Heart $J$ 2010, 31:112-9. | Article | PubMed

14. Rajpathak SN, Aggarwal $V$ and Hu FB: Multifactorial intervention to reduce cardiovascular events in type 2 diabetes. Curr Diab Rep 2010, 10:16-23. | Article | PubMed

15. Baldeweg SE and Yudkin JS: Implications of the United Kingdom prospective diabetes study. Prim Care 1999, 26:809-27. | PubMed

16. Stratton IM, Adler Al, Neil HA et al: Association of glycemia with macrovascular and microvascular complications in type 2 diabetes (UKPDS 35): prospective observational study. BMJ 2000, 321: 405-412. | Article

17. Mourad JJ and Le Jeune S: Blood pressure control, risk factors and cardiovascular prognosis in patients with diabetes: $\mathbf{3 0}$ years of progress. J Hypertens Supp/ 2008, 26:57-13. | Article | PubMed

18. American Diabetes Association. Standards of medical care in diabetes-2009. Diabetes Care 2009, 32(Suppl 1):S13-S61.

19. Baldwin MD: Assessing cardiovascular risk factors and selecting agents to successfully treat patients with type 2 diabetes mellitus. $J$ Am Osteopath Assoc 2011, 111:S2-12. I Article I PubMed

20. Shepherd J, Barter P, Carmena R, Deedwania P, Fruchart JC, Haffner S, Hsia J, Breazna A, LaRosa J, Grundy S and Waters D: Effect of lowering LDL cholesterol substantially below currently recommended levels in patients with coronary heart disease and diabetes: the Treating to New Targets (TNT) study. Diabetes Care 2006, 29:1220-6. | Article I PubMed

21. Chittleborough CR, Baldock KL, Phillips PJ and Taylor AW: Achievement of management targets associated with incident and long-term diagnosed diabetes among a representative population sample. Diabetes Res Clin Pract 2010, 88:322-7. | Article | PubMed

22. Patel A, MacMahon S, Chalmers J, Neal B, Woodward M, Billot L, Harrap S, Poulter N, Marre M, Cooper M, Glasziou P, et al: Effects of a fixed combination of perindopril and indapamide on macrovascular and microvascular outcomes in patients with type 2 diabetes mellitus (the ADVANCE trial): a randomised controlled trial. Lancet 2007, 370:829-40. | Article | PubMed

23. Turner RC, Millns H, Neil HA, Stratton IM, Manley SE, Matthews DR and Holman RR: Risk factors for coronary artery disease in noninsulin dependent diabetes mellitus: United Kingdom Prospective Diabetes Study (UKPDS: 23). BMJ 1998, 316:823-8. | Article | PubMed Abstract I PubMed Full Text

24. Selvin E, Marinopoulos S, Berkenblit G, Rami T, Brancati FL, Powe 
NR and Golden SH: Meta-analysis: glycosylated hemoglobin and cardiovascular disease in diabetes mellitus. Ann Intern Med 2004, 141:421-31. | Article | PubMed

25. Estacio RO, Jeffers BW, Gifford N and Schrier RW: Effect of blood pressure control on diabetic microvascular complications in patients with hypertension and type 2 diabetes. Diabetes Care 2000, 23 Suppl 2:B54-64. | Article | PubMed

26. Roger A. Rodby, Richard D. Rohde, William R. Clarke, Lawrence G. Hunsicker, Deborah A. Anzalone, Robert C. Atkins, Eberhard Ritz and Edmund J. Lewis: The Irbesartan type II diabetic nephropathy trial: study design and baseline patient characteristics. For the Collaborative Study Group. Nephrology Dialysis Transplantation. [Clinical Trial Comparative Study Multicenter Study Randomized Controlled Trial Research 2000, 15:487-97. | Article

27. Pignone $M$ and Williams $C D$ : Aspirin for primary prevention of cardiovascular disease in diabetes mellitus. Nat Rev Endocrinol 2010, 6:619-28. | Article | PubMed Abstract | PubMed Full Text

28. Ovalle F: Cardiovascular implications of antihyperglycemic therapies for type 2 diabetes. Clin Ther 2011, 33:393-407. I Article I PubMed

29. Patel A, MacMahon S, Chalmers J, Neal B, Woodward M, Billot L, Harrap S, Poulter N, Marre M, Cooper M, Glasziou P, Grobbee DE, Hamet P, Heller S, Liu LS, Mancia G, Mogensen CE, Pan CY, Rodgers $A$ and Williams $B$ : Effects of a fixed combination of perindopril and indapamide on macrovascular and microvascular outcomes in patients with type 2 diabetes mellitus (the ADVANCE trial): a randomised controlled trial. Lancet 2007, 370:829-40. | Article | PubMed

30. Ferrannini E, Betteridge DJ, Dormandy JA, Charbonnel B, Wilcox RG, Spanheimer R, Erdmann E, Defronzo RA and Laakso M: High-density lipoprotein-cholesterol and not $\mathrm{HbA1C}$ was directly related to cardiovascular outcome in PROactive. Diabetes Obes Metab 2011, 13:759-64. | Article | PubMed

31. Calvert MJ, McManus RJ and Freemantle N: The management of people with type 2 diabetes with hypoglycaemic agents in primary care: retrospective cohort study. Fam Pract 2007, 24:224-9. | Article I PubMed

32. Agban H, Elley CR, Kenealy $T$ and Robinson $E$ : Trends in the management of risk of diabetes complications in different ethnic groups in New Zealand primary care. Prim Care Diabetes 2008, 2:181-6. | Article | PubMed

33. Krass I, Hebing R, Mitchell B, Hughes J, Peterson G, Song YJ, Stewart K and Armour CL: Diabetes management in an Australian primary care population. J Clin Pharm Ther 2011, 36:664-72. | Article | PubMed

34. Lipscombe LL and Hux JE: Trends in diabetes prevalence, incidence, and mortality in Ontario, Canada 1995-2005: a population-based study. Lancet 2007, 369:750-6. | Article | PubMed

35. Zhi J, Melia AT, Guerciolini R, Chung J, Kinberg J, Hauptman JB and Patel IH: Retrospective population-based analysis of the doseresponse (fecal fat excretion) relationship of orlistat in normal and obese volunteers. Clin Pharmacol Ther 1994, 56:82-5. | Article | PubMed

36. Tonstad S, Pometta D, Erkelens DW, Ose L, Moccetti T, Schouten JA, Golay A, Reitsma J, Del Bufalo A, Pasotti E and et al.: The effect of the gastrointestinal lipase inhibitor, orlistat, on serum lipids and lipoproteins in patients with primary hyperlipidaemia. Eur J Clin Pharmacol 1994, 46:405-10. I Article I PubMed

37. Griffin SJ, Borch-Johnsen K, Davies MJ, Khunti K, Rutten GE, Sandbaek A, Sharp SJ, Simmons RK, van den Donk M, Wareham NJ and Lauritzen T: Effect of early intensive multifactorial therapy on 5-year cardiovascular outcomes in individuals with type 2 diabetes detected by screening (ADDITION-Europe): a cluster-randomised trial. Lancet 2011, 378:156-67. | Article | PubMed Abstract | PubMed Full Text

38. Group EPOC: The Cochrane Effective Practice and Organisation of Care Review Group Data Collection Checklist. Aberdeen, UK: University of Aberdeen, 1998, 1-30.

39. Bero LA, Grilli R, Grimshaw JM, Harvey E, Oxman AD and Thomson $M A$ : Closing the gap between research and practice: an overview of systematic reviews of interventions to promote the implementation of research findings. The Cochrane Effective Practice and Organization of Care Review Group. BMJ 1998, 317:465-8. | Article | PubMed Abstract I PubMed Full Text

40. Higgins J, Green S: Cochrane Handbook for Systematic Reviews of Interventions: The Cochrane Collaboration. 2009. Accessed 2 March 2011. Available from: | Website

41. Gaede $P$ and Pedersen O: Multi-targeted and aggressive treatment of patients with type 2 diabetes at high risk: what are we waiting for? Horm Metab Res 2005, 37 Suppl 1:76-82. | Article | PubMed

42. Pedersen $O$ and Gaede $P$ : Intensified multifactorial intervention and cardiovascular outcome in type 2 diabetes: the Steno- $\mathbf{2}$ study. Metabolism 2003, 52:19-23. | Article | PubMed

43. Gaede P, Vedel P, Larsen N, Jensen GV, Parving HH and Pedersen O: Multifactorial intervention and cardiovascular disease in patients with type 2 diabetes. N Engl J Med 2003, 348:383-93. | Article | PubMed

44. Guo LX, Pan Q, Wang XX, Li H, Zhang LN, Chi JM and Wang Y: Effect of short term intensive multitherapy on carotid intima-media thickness in patients with newly diagnosed type 2 diabetes mellitus. Chin Med $J$ (Engl) 2008, 121:687-90. | Article | PubMed

45. Chan JC, So WY, Yeung CY, Ko GT, Lau IT, Tsang MW, Lau KP, Siu SC, Li JK, Yeung VT, Leung WY and Tong PC: Effects of structured versus usual care on renal endpoint in type 2 diabetes: the SURE study: a randomized multicenter translational study. Diabetes Care 2009, 32:977-82. | Article | PubMed Abstract | PubMed Full Text

46. Agewall S, Wikstrand J, Samuelsson O, Persson B, Andersson OK and Fagerberg B: The efficacy of multiple risk factor intervention in treated hypertensive men during long-term follow up. Risk Factor Intervention Study Group. J Intern Med 1994, 236:651-9. | Article | PubMed

47. Gaede P, Lund-Andersen H, Parving HH and Pedersen O: Effect of a multifactorial intervention on mortality in type 2 diabetes. $N$ Engl $J$ Med 2008, 358:580-91. | Article | PubMed

48. Janssen PG, Gorter KJ, Stolk RP and Rutten GE: Randomised controlled trial of intensive multifactorial treatment for cardiovascular risk in patients with screen-detected type 2 diabetes: 1-year data from the ADDITION Netherlands study. Br J Gen Pract 2009, 59:43-8. | Article | PubMed Abstract | PubMed Full Text

49. Guo LX, Pan Q, Wang XX, Li H, Zhang LN, Chi JM and Wang Y: Effect of short term intensive multitherapy on carotid intima-media thickness in patients with newly diagnosed type 2 diabetes mellitus. Chin Med $J$ (Engl) 2008, 121:687-90. | Article | PubMed

50. Joss N, Ferguson C, Brown C, Deighan CJ, Paterson KR and BoultonJones JM: Intensified treatment of patients with type 2 diabetes mellitus and overt nephropathy. QJM 2004, 97:219-27. | Article | PubMed

51. Hawthorne K, Robles Y, Cannings-John R and Edwards AG: Culturally appropriate health education for Type 2 diabetes in ethnic minority groups: a systematic and narrative review of randomized controlled trials. Diabet Med 2010, 27:613-23. | Article | PubMed

Citation:

Khalil H, Namara K M and Y P: Multiple pharmacological interventions targeting cardiovascular disease risk factors in individuals with type 2 diabetes-systematic review. Journal of Diabetes Research and Clinical Metabolism 2013, 2:9. http://dx.doi.org/10.7243/2050-0866-2-9 